\title{
Shils and the Intellectuals
}

\section{Jefferson D. Pooley}

\author{
Muhlenberg College \\ pooley@muhlenberg.edu \\ jeffpooley.com
}

\begin{abstract}
This is a post-peer-review version of the chapter. The final authenticated version is available online at https://doi.org/10.7765/9781526120069.00014.

Jefferson Pooley. "Shils and the Intellectuals." In The Calling of Social Thought: Rediscovering the Work of Edward Shils, edited by Christopher Adair-Toteff and Stephen Turner, 171-190. Manchester: Manchester University Press, 2019. https://doi.org/10.7765/9781526120069.00014
\end{abstract}




\section{Shils and the Intellectuals}

Jefferson Pooley, Muhlenberg College, pooley@muhlenberg.edu

doi

Introduction

No topic so CONSISTENTLY preoccupied Edward Shils, at every stage of his career, as the intellectual. Most of his reflections concerned the intellectual's fraught relationship with the societies that harbour them. This chapter traces Edward Shils' distinctive conception of the intellectual-as indispensable to, but all too often an opponent of, social order. During his undergraduate years in the late 1920s, Shils had already become fascinated with, and repulsed by, the tendency that he observed among intellectuals to despise their own societies. His aversion to intellectual disloyalty was a constant throughout his adult life, though his specifically 'Shilsian' take on the intellectual and his society would only cohere, in a sophisticated, original, and consistent way, in the 1950s.

This chapter reconstructs Shils' encounter with the downcast intellectual, first as a precocious reader of Gustave Flaubert, Hippolyte Taine, Hendrik de Man, Robert Michels, and, above all, Georges Sorel. It was Sorel's chiliastic politics of heroic violence which, in its purist clarity, helped disclose the transcendent moral impulse that, to varying degrees, leads intellectuals to judge their societies harshly. When, after the Second World War, the moral ideal seemed spent even within socialist movements, Shils observed its traces in the complaints of ex-radicals - 'disappointed and broken-down Trotskyites and Edelmarxisten, most of Frankfurt provenance' (1972C: xi). Once Shils, in the post-war years, came to identify intellectual crankiness about social disintegration with the threat of real social disintegration, the failure to recognize the invisible lines of consensus in society was tantamount to fraying them. Society's loose consensus depends on public belief, Shils argued, which in turn depends on the social picture put forward by intellectuals. These 'persons with an unusual sensitivity to the sacred' ([1958a] 1972a: 3) could help support the fragile achievements of civil politics, but he was not optimistic.

\section{Shils' theory of intellectuals}

Shils first published his mature theory of the intellectual in the late 1950s. In 'The Intellectuals and the Powers' ([1958a] 1972a) and sub- 
sequent work, he classified intellectuals as those rare individuals drawn to the sacred. Every society throughout human history has had individuals like this-a minority drawn to contemplate the ultimate nature of things, and to express its reflections in fables, poetry, art, and ritual performance. The original and sustaining impulse for intellectual work, Shils claimed, was religious: before the rise of secular traditions of intellectual life in the modern West, most intellectuals wrestled with the 'ultimate or at least with what lies beyond the immediate concrete experience' through religious symbols (Shils, [1958a] 1972a: 16). Even secular intellectuals share with religion the preoccupation with the sacred, and the 'aspiration to enter into intimate contact with it' (Shils, [1958a] 1972a: 16):

Intellectual action of an intense kind contains and continues the deeper religious attitude, the striving for contact with the most decisive and significant symbols and the realities underlying those symbols. It is therefore no stretching of the term to say that science and philosophy, even when they are not religious in a conventional sense, are as concerned with the sacred as religion itself. (Shils, [1958a] 1972a: 16)

With this transhistorical, religious substrate in mind, Shils made his second major claim: that intellectuals, in every society, are indispensable to social order. He spelled out several major functions that intellectuals serve, in what amounts to a normative standard. Through preaching and writing, they connect the rest of the population (the laity), however fleetingly, to remote symbols and the wider universe. By example and through their creations, intellectuals also stand as models for a society's cultural life. In both respects intellectuals foster the laity's attachment to the 'central value system' (Shils, [1958a] 1972a: 7). More directly, intellectuals are often in positions of administrative power, and otherwise serve as counsellor to the sovereign. From Aristotle and Alexander, through to Franklin Delano Roosevelt's 'Brain Trust', intellectuals have furnished advice to princes and rulers, and occasionally-in the case of rare figures like William Gladstone-held power themselves. Even the prevailing ideals of modern politics, including nationalism and liberal constitutionalism, are the handiwork of intellectuals.

In the 'Powers' essay and other writings from the period, Shils wrote in unmistakably reverent terms about his fellow intellectuals. He plainly identifies with the intellectual's need to 'penetrate beyond the screen of immediate concrete experience' (Shils, [1958a] 1972a:

3). But Shils' Romanticism was tempered by what he described as an irresolvable tension between the intellectual's transcendent impulse and his attachments to his society. The intellectual's orientation to the ideal, and to the universal, generates at least a measure of alienation from his polity, its people, and its leaders. The disaffection that 
results is both inescapable and potentially healthy. By challenging inherited values, intellectuals supply alternative models for integrating their societies-'a crucial part of the intellectual heritage of any society' (Shils, [1958a] 1972a: 7). And the intellectual's alienation can, and often is, bounded: a commitment to civil politics and constitutional order is compatible with sensitivity to the sacred. But the same orientation to transcendence has, especially in modern times, led intellectuals to reject their nations and leaders with totalizing zeal. Many have embraced what Shils had come to call 'ideological politics': a commitment to the revolutionary reordering of society. This apocalyptic tendency of modern intellectuals is what Shils set out to explain and refute.

So Shils' work on intellectuals was a redemptive project, centred on attachment: how, and in what ways, might more intellectuals come to feel affinity for the societies in which they live? He located some living examples, including the scientific community in general (e.g. Shils, 1954b) and post-war British intellectuals in particular (Shils, 1955b). He also held out hope, in the mid-1950s at least, that 'ideological enthusiasm' might be on the wane (Shils, 1955c: 53). It is the task of the 'statesman and the responsible intellectual,' he wrote in the 'Powers' essay, to locate an 'optimum balance' between transcendence and civility-a 'requirement for order and continuity in public life and for the integration of the wide reaches of the laity into society' ([1958a] 1972a: 21). Social solidarity, perhaps especially in complex, pluralist societies, depends on intellectual attachment.

Even during his brief end-of-ideology flirtation of the mid-1950s, Shils was quick to concede that a disturbingly large stratum of intellectuals in the West, and in the postcolonial 'new states', clung to millenarist politics. And even those who had lost their revolutionary faith all too frequently brandished their deflated ideals as weapons against their own societies and mass cultures. Both modes of rejection were intimately familiar to Shils, and had been for decades.

\section{Shils' education}

By his own account, Shils' undergraduate years at the University of Pennsylvania were a four-year immersion in self-guided reading. The sheer volume that he recalls-Durkheim's entire oeuvre, for example (Shils, 1975e: xix) - is only plausible in light of Shils' lifelong and voracious bookishness. He majored in French Literature, and focused on nineteenthcentury writers and, in particular, Gustave Flaubert. In the course of his literary readings-mostly French, but also American, English, German, and Russian (Shils, 1982C: xxi, 1975e: xiv)Shils also consumed a 'vast amount of nineteenth-century political 
and belletrist literature' (Shils, 1972b: vii). It puzzled him that so many of these writers and thinkers, Flaubert above all, rejected their own societies with such venom. Intrigued and repulsed, Shils went about trying to understand these writers' scabrous alienation: 'Why did writers, historians, philosophers and other intellectuals, some great and all interesting, feel such revulsion for their own societies, for the institutions through which they were ruled and the persons who ruled them?' (Shils, 1972b: vii). ${ }^{1}$ In many ways, this question became Shils' core preoccupation throughout his career, though his explanation for intellectuals' 'comprehensive rejection of modern society' (Shils 1982c: xxii) would move through several iterations before settling in the 1950 .

It was this initial puzzle that drove Shils to the literature of Marxism and its critics. Based on his later remembrances, it is difficult to place encounters with specific authors in sequence, but he claimed special importance for Hendrik de Man's Psychology of Socialism ([1926] 1928), Robert Michels' Political Parties ([1911] 1915), and the works of Georges Sorel, especially Reflections on Violence ([1908] 1930). These books, read alongside Marxist tracts and the work of French counter-revolutionary historian Hippolyte Taine, helped Shils arrive at a tentative explanation for all that intellectual discontent (Shils, 1975e: xiv; 1972c: vii). Shils' thesis was that intellectuals' attraction to Marxism, as well as the broader intel- lectual contempt for society, had as their source a chiliastic moral impulse to heroic transcendence-expressed, in its pure form, by Sorel.

Shils claimed that his reading of the first volume of Taine's Origines de la France contemporaire (1875-93) was especially important to his emerging analysis of intellectuals. Taine, the philosopher and amateur historian, wrote his six-volume history of the Revolution after the humiliations of $1870-71$ - the Prussian defeat and the aftermath of the Paris Commune (see Pitt, 1998). Taine, whose historiographical care was quickly and decisively impugned, was nevertheless the leading Orléanist critic of the Third Republic and its liberal rationalist leadership (Peyre, 1949: 66n).

Taine used Tocqueville's (1856 [1998]) analysis of the ancien régime as his starting point, but he went much further than Tocqueville (or Burke) in laying the blame for the Revolution on Enlightenment ideals. Like Tocqueville, he pointed to the abstract rationalism of the philosophes as a major progenitor to what Taine famously called the 'Jacobin mind'. But Taine extended his irrationalist philosophical anthropology - his 'beast in man' pessimism-from the masses to the Enlightenment standard-bearers themselves: their humanitarian politics, their rationalist educational zeal, their law-making hubris-all of these, for Taine, were actually driven by unconscious resentment.

\footnotetext{
${ }^{1}$ In another memoir, Shils (1995a: 223) describes a more focused motivation: 'I took it as my task to understand why Flaubert hated his country and his fellow countrymen as passionately as he did.'
} 
The beast was still there, only - to use anachronistic languagerepressed and sublimated into Enlightenment and Revolutionary ideals. The masked irrationalism of the Revolutionary leadership and their philosophe forebears was all the more dangerous for its concealment. Taine's recourse to unconscious (and irrationalist) explanation for outwardly humane and rational thought was one direct and indirect source for many of the 'psychological' analyses of socialism in the late 1890 and into the twentieth century-including Gustave Le Bon's Psychologie du Socialisme (1898).

There is no evidence that Shils absorbed the particulars of Taine's analysis of the Enlightenment unconscious. ${ }^{2}$ Shils' end-of-college explanation for the societal hatred of literary men did not, for example, rest on a Tainelike thesis of atavistic beastliness. Indeed, Shils would come to attribute intellectuals' crankiness and sometime Promethean political impulses to a perfectionist moral ideal that rendered protean politics or bourgeois culture repugnant by contrast. More than anything, it was Taine's obsessive focus on Rousseau as chief antecedent villain of the Revolution that, in combination with Shils' own reading of Sorel and de Man, helped iden- tify the heroic ethical fervour that, to Shils, drove radical politics and this-worldly disdain. Taine was not the first, and certainly not the last, to link Rousseau's writings to catastrophic Revolutionary ideals, but his lengthy and detailed denunciation in the Origines influenced Shils' own reading of Rousseau.

Shils' reaction to Rousseau was, however, ambiguous and, in one respect, even admiring: for all his 'abhorrence' with the notion of a volunté générale, he was intrigued by the idea of individual absorption into some transcendent order. Shils reacted in a similar, almost schizophrenic manner to Sorel and to the ethical socialism of de Man and R. H. Tawney-in various memoirs, he claimed that these thinkers had helped to stir his appreciation for the necessity of moral ideals in binding societies together (Shils, 1975e: xx, 1950). But the ideal of complete absorption, linked as it was for Rousseau, Sorel, and indeed Marx to the promise of total individual freedom, struck him in these undergraduate years as 'both repugnant to me morally and unrealizable as well' (Shils, 1975e: xiv). Rousseau's 'noble savage' Romanticism, his reverse-Hobbesian chastisement of society, his fiery denunciations of inequality and ancient privilege, his popular consent-derived contractualism, and above all his apoplectic moralism-Shils recoiled from these, but came to understand the ethical impulse, in particular, as key to his original question.

This ethical impulse was clarified further for Shils in his encounters with the works of Michels, de Man, and especially Sorel (Shils, 1972b: vii, 1982c: xxii). All three thinkers, in distinct arguments, relayed to Shils important critiques of orthodox Marxism and, in
${ }^{2}$ Though in a general way, Shils seems to have absorbed the broader philosophes-French-Revolution thesis, anticipated by Tocqueville and Burke. He made frequent passing reference to the argument. For example, in his important essay 'Social Science as Public Opinion' ([1977] 1980a), he argued that disgruntled American sociologists are the 'contemporary equivalents of the philosophes of eighteenth-century France'. 
Michels and Sorel, of parliamentary socialism as well. De Man and Sorel amplified his interest in the cohesive role of shared belief, an interest that, of course, would prove central to his later analyses of the underpinnings of social order. But the core insight that Shils gleaned from his readings was his sense for the underlying moral drives that help explain intellectual discontent.

On a number of occasions, Shils referred to Michels' Political Parties ([1911] 1915) as an important undergraduate encounter (e.g. Shils, 1972b: vii). Michels' study was, among other things, an empirical debunking of Germany's Social Democratic Party—which, in contrast to its democratic socialist ideals, he found machine-like, bureaucratized, and dominated by a self-serving bourgeois elite. Michels famously extrapolated from his findings the 'iron law of oligarchy' - that hierarchy is an unavoidable feature of all organizations. His downcast take on what he called the 'problem of democracy' in 1911 had, by the 1919 second edition, given way to full alliance with the 'scientific opponents of democracy' (Scaff, 1981: 1281). The realist critique of the democratic (and socialist) ideal, Michels' as well as Mosca's and Pareto's, remained a life-long influence on Shils' own thinking about democratic politics, but after the Second World War Shils' endorsement of their picture was always qualified. ${ }^{3}$ It was, however, Michels' disillusioned radicalism itself — the contrast between his initially high ideals and his Machiavellian conclusions-that helped Shils along in his effort to understand intellectual alienation.

Michels' realism was so bleak and despondent because, measured against his Herculean ideals, it amounted to a cold bath. He had joined the Social Democratic Party as a reform-minded ethical socialist; his differences with the Party's leaders had led Michels to an association, starting in 1905, with Sorel and syndicalism. Sorel, in this period, was composing the Reflections, and attracted Michels to his anti-institutional politics of heroic direct action. On the encouragement of Max Weber-who dismissed Michels' syndicalism, but was impressed by his analytic acumen

Michels published his first study of the Party in Weber's Archiv für Sozialwissenschaft und Sozialpolitik in September 1906, deliberately timed as a provocation to his erstwhile party colleagues gathered at their annual Congress. As early as 1907, Michels drifted from the syndicalists too, for their failure to live up to their own high ideals. The 1911 publication of Political Parties registered Michels' steady disillusionment with the failures of political reality as well as actually existing radicalism. Weber, in correspondence, repeatedly chastised Michels for his naïve hopes and his despairing conclusions about democracy, which Weber found far too sweeping. Michels' bitter disappointment, Weber observed, was the predictable flip-
${ }^{3}$ See, for example, 'There is undoubtedly much truth in these writers, but they only saw a part and claimed to speak for the whole' (Shils, 1950: 19). 
side to his absurdly perfectionist ideals. He was, in Weber's term, a Gesinnungsethiker gripped by the desire for ethical purity, and predictably chastened at the world's corruption. Michels' own shifting allegiances over the years-from ethical socialism, to syndicalism, to scientific elitism, to nationalism, and then to Fascism—seemed to bear out Weber's observations.

Shils implies that Michels' book served as a model of disappointed radicalism only in the context of his undergraduate project to understand intellectual alienation. He certainly did not know about the Weber connection until a few years later-and then only through Marianne Weber's memoirs. He also probably lacked knowledge of Michels' political evolution on first reading, though the book itself openly betrays its author's radical disillusionment. In any event, Shils made the pendulum-like connection between radical hope and bitter disappointment in his reading of Sorel. And the category of the post-war God-that-failed ex-Communist is analysed by Shils, in the 1950s, in just these terms.

Hendrik de Man, the Belgian socialist thinker and prominent Depression-era parliamentarian and party leader, wrote his Psychology of Socialism in 1926 while studying in Weimar Germany. De Man became famous for his 1930 s 'plan-de-Man' call for wide-scale government intervention in the Belgian economy-and infamous for his 1940 collaboration with the Nazis, which probably accounts for his obscurity today (Hansen, 1981; Pels, 1991). Psychology of Socialism, as Stephen Turner (1999: 127-9) points out, was one expression of a general crisis of Marxism in the 1920s in the aftermath of the failed post-world-war Central European revolutions, Lenin's vanguardist revolution against Kapital, and above all the apparent quiescence of the working class.

The originality of de Man's books rests on its critique of Marxism's psychological myopia-its failure to understand (and thereby cultivate) the traditional moral underpinnings of working-class discontent and its corresponding blindness to the distinct motivation of (mostly bourgeois) socialist intellectuals. Tradition, de Man argued, did not weigh like a nightmare on the brain of the living as, in the Marxist view, a residual form of false consciousness. Unfulfilled, often Christian ethical principles, for de Man, are the motivation for workers' embrace of socialism.

De Man also dismissed the notoriously thin account of the intellectual in orthodox Marxist theory. Like many others, he was haunted by Socialist and Communist Party 'embourgeoisement' and bureaucratization, in part on account of Michels' realist critique of the German Social Democratic Party (Pels, 2002: 284). De Man hoped that by unmasking the revolutionary intellectual's distinct motives he could 
dampen their 'chiliastic expectations' and thereby recruit them to his evolutionist socialist vision. Leftist intellectuals, he argued, are motivated by resentment of their 'unrecognized genius'; though they often embrace the 'science' of Marxism, they are driven, ultimately, by the Fabian ideal that in the future 'the acquisitive motive of the capitalist and the worker will be replaced by a new motive, that of service to community'. De Man insisted that this ideal is really a 'desire to make all members of the community into intellectuals' (1926 [1928]: 222).

Shils later acknowledged that de Man's sensitivity to society-wide traditional beliefs had an impact on his then-embryonic thinking about social order. But de Man's most important contribution, especially in light of Shils' undergraduate project to understand intellectual antinomianism, was his analysis of the unconscious motives of left intellectuals. De Man had suggested that intellectual chiliasm derives from a contrast between a perfectionist moral ideal and the grubbiness of everyday politics and culture. This is precisely the contrast that Shils observed, in apotheotic terms, in Georges Sorel's 'heroic sublimity' (Shils, 1950: 19).

Referring to his undergraduate reading of Michels and de Man, Shils wrote: 'These writers made me ask the question: Why did writers, historians, philosophers and other intellectuals, some great and all interesting, feel such revulsion for their own societies, for the institutions through which they were ruled and the persons who ruled them?' (1972C: vii)

It was Sorel who provided Shils the key to his puzzle of the discontented intellectual-though not because Sorel's general-strike syndicalism was especially influential. For Shils, Sorel was important, instead, as an especially clear window into the intellectual soul, unobstructed by the apathy, resignation, or bohemianism that is, in so many others, its surface manifestation. Sorel's ethical extremism was, in a sense, the purest expression of a moral ideal that other intellectuals harbour too in less apparent ways. Sorel, Shils recalled in a memoir (1975e: xiv), 'made an unpleasant but nonetheless deep impression on me'. Along with de Man, Taine, and others, Shils credited Sorel for helping to reinforce his nascent belief in the 'notion that a society has a set of moral and cognitive beliefs, adherence to which is a condition of its survival' (1975e: xiv). But it was Sorel's pure chiliasm, his unambiguous orientation to ultimate values, and his all-ornothing moral temperament that provided, for Shils, a glimpse into the intellectual psyche-and, by extension, a way to understand intellectuals' 'oppositional mentality' as derivative of a transcendent moral ideal (see, e.g., Shils, [1957] 1975a: 138-9). 
Sorel's rejection of existing society was near-total. He was, in a sense, a Flaubert engagé who despised, especially, bourgeois decadence and corruption. His heightened sensitivity to hypocrisy and hollow idealism made him a critic, too, of Marxism and especially parliamentary socialism. Indeed, his observations about the inevitability of elite dominance famously fuelled the democratic 'realism' of Mosca and Pareto-only, for Sorel, the corruption of bourgeois and socialist parties could be elided, in apoplectic violence. He rejected not just Marxist economism but even its implicit utopia as unrealistic and intellectualist; he remained a Marxist only if 'social poetry' counts as Marxism.

Especially in his late nineteenth-century years, Sorel was a conservative moralist and always, even as a syndicalist, rejected the typical leftist call for sexual emancipation. He claimed respect for ancient tradition and especially religious sentiment, for they draw on the fundamental human capacity to believe, the 'faculté mystique'. Sorelian myths, and the revolutionary myth of the general strike in particular, are meaning-drenched calls to action, designed to appeal to that non-rational will to believe. Sorel largely accepted Gustave Le Bon's portrait of crowd psychology, but without Le Bon's trepidation; in a violent mob, man has reached closest to his irrational essenceclosest, that is, to that 'profounder region of our mental life' (Sorel, 1908 [1930]: 30; see also Nye, 1973, 1977). The myth of the general strike was to be a rousing call to purifying violence, a striving for 'total and simultaneous emancipation' (Sorel, 1987: 109). For Sorel, the ethic was in the act itself, the cleansing violence-and not in any imagined, placid end-state. The general strike, in this sense, was for Sorel an uncompromising refusal to live in the world as it is, in all its squalid corruption.

In his unceasing quest for ethical regeneration, Sorel moved through conservative moralism, Marxism, syndicalism, authoritarian traditionalism (in 1910), and then on to sympathetic Bolshevism before his death in 1922. Common to all his political guises, Shils observed, was a single principle: 'the highest good is the heroic (i.e. aggressive) action performed with a sense of impersonal consecration to the ends of a restricted, delimited group bound together in fervent solidarity and impelled by a passionate confidence in its ultimate triumph in some cataclysmic encounter' (1950: 18).

Sorel's impact was so profound that Shils outlined a book on Sorel while an undergraduate, which he was still planning to write when he arrived in Chicago in 1932 (Shils, 1982b: xxii, [1957] 1975a: 119). Shils' picture of the discontented intellectual, when he left the campus and Philadelphia, was by no means fully formed; his mature theory, with reference to the 'sacred' and 'earthly centres', would 
emerge more than twenty-five years later, and only after a second intense encounter with Sorel in the late 1940s. But his youthful reading of Sorel—and also, in different ways, of Michels and de Man provided an answer to that original enigma: 'why Flaubert hated his country and his fellow countrymen as passionately as he did' (Shils, 1995a: 223). In a memoir (1982c: xxii), he recalled that his undergraduate reading of Sorel, de Man, and others helped him gain a 'better understanding' of intellectuals' 'comprehensive rejection of modern society', on the grounds, he wrote, of its 'materialistic disregard for the realm of transcendent things'.

\section{Shils and social thought}

Shils spent the first half of the 1930s acquiring detailed knowledge of twentieth-century German social thought. He spent the second half of that decade fretting alongside German refugees about the fate of modern society. Both encounters helped shape his aggrieved response, after the war, to the criticism of American culture by fellow intellectuals.

Like many American intellectuals in the 1930s, Shils was forced to make sense of the economic Depression of that decade-which, as he later recalled, he 'learned from the experience of my own family and our neighbours as well as from my experience as a social worker in New York and Chicago' (Shils, 1975e: xxix). But Shils was not, like his fellow intellectuals, primarily oriented to the American Depression or even to the limited American critique of democratic theory. He was, as he put it, 'brought up intellectually' in France, the UK, and Germany; the ascendance of the Nazis and other Fascist regimes were 'events of almost overwhelming significance' to him (1975e: xxix). His 'exiled friends' were the living embodiments of a collapsed society - the scattered and scarred remnants of a revered intellectual culture (1975e: xxix). Many of them were victims, too, of the regime's violent—and ultimately genocidal-anti-Semitism. Shils' fieldwork among Nazi sympathizers on Chicago's North Side, in 1941, was almost certainly motivated by his own desire to understand the German catastrophe and its prospects in America (see Shils, [1957] 1975a: 134, 1975a: xxiii).

By the time Shils graduated from the University of Pennsylvania in 1931, he had already developed a deep reverence for German scholarship. He later claimed that his interest went back all the way to his childhood: he remembered visiting the University's museum of Middle Eastern antiquities when he was about ten, and noticed then that many of the exhibit descriptions indicated that the originals were in Berlin (Shils, 1972b: xi). By the late 1920s, as an undergradu- 
ate, he began to teach himself the language by struggling, 'word for word', through Max Weber's posthumous Wirtschaftsgeschichte [General Economic History] ([1923] 1927) and the first volume of Werner Sombart's Der moderne Kapitalismus [Modern Capitalism] (1916) (Shils, 1995a: 221). He recalls spending his evenings 'looking up most words in the Muret Saunders dictionary', without much comprehension: 'I would vaguely decipher a whole sentence sometimes' (1995a: 221).

After graduating from Penn in the midst of the Depression, Shils spent a year in New York-he later called it an 'enthusiastic weltschmerz' - as a social worker in training (Shils, 1981b: 186). He apparently devoted most of his time to reading: 'That year was spent in delighted discovery of the scintillating insights of Georg Simmel, helpless pondering on Dilthey's Einleitung (Introduction) and, in the salt-mine-like labour in reading word for word Weber's Das antike Judentum (Ancient Judaism), which caused me to have to look up almost every word' (Shils, 1995a: 222). His German gradually improved over the course of the year, so much so that he reports reading Rilke's Notebooks with 'some reasonable understanding' (1995a: 222). By the time he left New York, he had acquired the 'notion that German professors were the true professors, the very idea of professors' (Shils, 1981b: 179). The Humboldtian university would remain, throughout his life, his academic ideal.

Shils left for Chicago in the autumn of the following year, 1932, with the hope of studying at the University of Chicago, and soon found work as a social worker in what was then called the 'Black Belt' (Shils, 1981b: 186). A childhood friend, just returned from his own study at the University, had enticed Shils by his account of the economist Frank H. Knight's 'somber and unremitting search for truth' (Shils, 1995a: 222). Shils was also drawn west by the sociologist Robert E. Park, whom he had read as an undergraduate. With Park travelling in Asia at the time, Shils arranged to meet Louis Wirth, the young sociologist and former Park student, on his first day in Chicago (Shils, 1981b: 186). Shils had been impressed by Wirth's The Ghetto (1928), which he had read-of course—at Penn. Though Shils would later come to think of him as a relative lightweight, Wirth's recent trip to Germany was proof enough of his intellectual stature. 'Meeting with Wirth was, for me, to be in contact with Germany. To be in contact with German universities was to be in contact with the great tradition of learning' (Shils, 1981b: 186).

Wirth recognized his student's grasp of German and invited Shils a few months later to serve as his research assistant. Wirth soon recruited Shils to help translate Karl Mannheim's Ideologie und Utopie [Ideology and Utopia] ([1929] 1936) — a translation that Shils largely completed on his own. Shils served as the sole translator of 
Mannheim's next book, Mensch und Gesellschaft im Zeitalter des Umbaus [Man and Society in an Age of Reconstruction] ([1929] 1940), and Shils and the Hungarian émigré struck up an intense, if also complicated, friendship that lasted until Mannheim's death in 1947 (see Pooley, 2006: 86-100, 132-50; 2007).

It was during this early Chicago period that Shils first read Weber's 'Wissenschaft als Beruf' ['Science as a Vocation'] ([1919] 1946a), which, as he noted frequently, made 'a great impression on $\mathrm{me}^{\prime}$. As for so many others, Weber's Heidelberg address would become one of Shils' guiding texts, then and for the rest of his life. Weber's warnings against the 'miserable monstrosities' of the 'academic prophecy' -alongside his wary treatment of the 'ethic of ultimate ends' in 'Politics as a Vocation' ([1919] 1946b) —would provide, for Shils, a standpoint to critique the political Prometheanism of the intellectual Left (Shils, 1972b: vii). ${ }^{4}$ Indeed, as he later (1975e: xxx) remarked, the essay helped make sense of his own undergraduate thoughts on the antinomian intellect.

In the course of his work for Wirth and Mannheim, Shils became acquainted with a number of intellectual refugees from the Nazi regime including Hans Speier, Alexander von Schelting, Ernst Fränkel, Hans Gerth, Franz Neumann, and Mannheim himself. These encounters were significant for Shils in a number of fascinating ways. Speier and von Schelting, for example, helped wrest Shils from his embrace of a Mannheimderived epistemology centred on the social genesis of ideas (Shils, 1995a: 225, 231; Kettler and Meja, 1995). As part of his help to a late-emigrating Gerth, to take another example, Shils heavily edited (and may have largely written) Gerth's well-known (1940) paper on the Nazi Party (Shils, [1957] 1975a: 11516; Oakes and Vidich, 1999). His immersion in the émigrés' often frantic attempts to explain the Weimar collapse and the nature of the Nazi regime-notably including Fränkel's The Dual State (1941), which Shils translated so that Fränkel could establish himself in the AngloAmerican world (Shils, 1975a: xxiv)—exposed him to a succession of bleak accounts, set in a despairing and traumatized key. His friendships with the émigrés - the dispersed and shell-shocked remnants of the Weimar intellectual culture that was, in a sense, his first academic passion-seems to have blackened his already dark mood. Shils' own crisis, put differently, was an amplified and distinctly tangible version of the crisis in American liberalism that had, by the mid-1930s, emerged out of the Depression and the distant rumble of Fascism. 5

Through his contact with the intellectual refugees, Shils was bathed in their acrid, 'disaster-triumphant' distress. Franz Neumann (1953: 13), in his haunting commentary, described the psychological
${ }^{4}$ Shils: 'It helped to define a standpoint from which the fellow-traveling and the communist intellectuals of the 1930 s were to be criticized' (1972c: vii).

\footnotetext{
${ }^{5}$ In a mid-1930s letter to his friend Torsten Gordland, Shils wrote: 'In the larger world, things are positivity sickening. Only the most fanatical or the most resolute and purposeful
} 
trauma of many émigrés: 'Being compelled to leave their homeland, they thus suffered the triple fate of a displaced human being with property and family; a displaced scholar; and a displaced homo politicus.' Even among the intellectuals that Shils came to know, there existed an enormous political and scholarly diversity-not everyone experienced Frankfurt-style 'Grand Hotel Abyss' estrangement, especially after adjusting to American or English conditions. But there was, from Mannheim to Speier to Fränkel, a sense of despair and disorientation at the violent shattering of German civilization. The Weimar collapse greatly amplified the already widespread cynicism among intellectuals concerning the viability of consensual, democratic politics. If the two students of Weber, Mannheim and Carl Schmitt, could be thought to offer, in the 1920s, competing responses to Weber's qualified critique, in particular, of democratic rhetoricone hopeful, the other coldly cynical-the Weimar collapse settled the matter, for many émigrés including Mannheim, in Schmitt's tragic favour. The Frankfurt scholars, including Neumann, as well as many others, had come to accept Schmitt's decisionist critique of parliamentary democracy, without of course conceding Schmitt's normative inferences (Kennedy, 1987).

Schmitt-derived or otherwise, there was widespread pessimism about the prospects for stable liberal democracy in the émigré community, especially in the years before the war (Gunnell, 1993: 165-74). Many of the émigrés, including those Shils knew, like Mannheim and Fränkel, laboured in writing to make sense of the Nazi calamity, and most of these-including Paul Tillich (1934), Emil Lederer (1940), Erich Fromm (1941), and Sigmund Neumann (1942), to name a few published before Shils joined the war effort-are the works of palpably shaken men. For Mannheim ([1929] 1940), the world really did seem a polar night of icy darkness.

So Shils formed his profound reverence for German academic achieve- ment just as his beloved Weimar conversation was coming to a violent close. At the same time, he came to link European intellectuals' otherworldly aspirations with the barbarous collapse of their own societies; he held them partly responsible for the calamities in Germany, Italy, and Soviet Russia. If Sorel had served as Shils' archetypical instance of intellectual Prometheanism, Mannheim came to seem like Sorel's shadow-the purest expression of after-the-fall intellectual dejection. When Shils, after the war, came to see intellectuals as the indispensable wardens of social order, he judged the émigrés' disintegrative despair to be an abdication, and a dangerous one. This was, in the end, the treason of the intel- lectuals: their doctrines of breakdown were untrue and deadly. Even the tragic Weimar collapse itself could seem to Shils (1972c: vii), in these later years, as persons can get any satisfaction from the way things are turning these daysthe former out of vested interest in a theory and the latter out of moral uprightness and devotion, neither of which virtue I can muster to any significant degree. I am almost being reduced to an intellectually obviously ridiculous \& fantastic wish for Heillösungen. And the truth is, dear Torsten, there is not a damned bit of relief anywhere-not one damned bit-person or superpersonal.' Letter to Torsten Gordland (20 September 1935). Edward Shils Papers. Special Collections Research Center, University of Chicago Library, folder Correspondence 1930s, Box 1, Series IIII. 
a kind of self-immolation: 'It seemed such a pity to me that the intellectuals should have been responsible for destroying a society which in so many respects had conferred such benefits on intellectuals.'

\section{Shils' worldview}

Like so many other American social scientists, Shils spent the years after the United States' entry into the Second World War working for the government. After brief stints in 1942 at the Federal Communications Commission's (FCC) Foreign Broadcast Intelligence Service and the Office of War Information, Shils joined the London branch of the Office of Strategic Services (OSS), precursor to the Central Intelligence Agency (CIA). In the war's last year, he worked on the Allied command's Psychological Warfare Division, interviewing German prisoners of war (Shils, 1948).

Shils' time in Europe transformed his worldview across a range of pre- occupations, including his picture of the intellectual (Turner, 1999; Pooley, 2007). Shils' contacts in London, with English and émigré intellectuals, helped along his new understanding, as did his intense study, in this period, of literature on early modern English religious tolerance. Above all, his wartime research on German prisoners of war contributed to his changed view: In trying to explain the extraordinary tenacity of the Wehrmacht in the face of certain defeat, Shils came to realize that close primary ties among small units-and not diffuse attachments to Nazism or the Fatherland - accounted for the soldiers' will to fight. On reflection, Shils came to see the persistence of primary ties as an overlooked feature of modern life- $\mathrm{a}$ feature that helped to undermine the more dissensual picture those around him had clung to in the pre-war years (Pooley, 2006: 121-7).

Shils, working with Morris Janowitz and Henry Dicks, interviewed dozens of German prisoners of war with the question of tenacity in mind: why did German soldiers maintain the fight, and with such disciplined resolution (Lerner, 1949: 109-10, 138; Shils, [1957] 1975a: 116)? Their obstinacy seemed to defy all the battlefield indicators that pointed, by late 1943, to near-certain Allied victory. If the German troops were resigned to inevitable defeat-Shils found that they indeed were- then why didn't they desert, surrender, or collapse? The mystery was only made more shadowy by the finding that soldiers, for the most part, were not National Socialist faithful, nor were they especially patriotic. Their rather sturdy morale could not be explained by delusions of battlefield optimism nor by fight-to-die belief commitments (Shils, [1957] 1975a: 116-18; 1975e: xxiii- xiv; 1988a: 266-7). 
The solidarity of the soldiers' smallest units had 'impressed' Shils -their loyalty to one another, their sense of camaraderie, their desire for esteem in their fellows' eyes (Shils, [1957] 1975a: 116-17). He came to regard these small-group attachments as the key fuel that kept the soldiers fighting. The Wehrmacht itself, Shils argued, could be conceived as unit-sized solidarities knit together-as a network of cohesive small groups. Shils was, of course, also preoccupied with the broader question of social order, and the primary group seemed to help explain how it is that modern societies manage to hang together. Even if large-scale societies could not take on the properties of small groups-and Shils remained sceptical of the vision he ascribed to Charles Horton Cooley, that of one big primary group-the overall stability of these societies depend, nevertheless, on a substrate of small-group loyalty.

Though in later accounts Shils admitted that he had had trouble in these years explaining how primary group ties translate into national-scale order, he became convinced that these groups mediated-absorbed and redeployed somehow—-the appeals of ideology and national symbolism. He did not dismiss the importance of National Socialist belief, patriotic pleas, nor the bureaucratic chain of command; but for most of the troops, these were not the salient factors in their will to fight (Shils, 1975e: xxiv; 1988a: 267). In the immediate post-war years Shils and Janowitz ([1948] 1975a) wrote up their results in a now-classic paper. Primary groups, they argued, are modernity's answer to scale and impersonality: these clusters provide otherwise-scarce affective sustenance while at the same time remain linked up, through member-mediators, to the more expansive bonds of nationalism and belief.

Shils' observations, readings, and contacts in wartime London gave him, too, a new and half-formed appreciation for the distinct and particular achievements of the English liberal tradition (Pooley, 2006: 127-31). In a 1975 memoir, Shils recalled reading deeply in the literature on religious dissent and toleration in seventeenthcentury England, though he never published in the area (Shils, 1975e: xxiii). ${ }^{6}$ Shils' studies of English religious toleration helped to shape his emerging attentiveness to an English tradition of elite and civil governance that had, since the eighteenth century, been adapting successfully to the emerging reality of popular input (Turner, 1999: 138). The unspoken limits on political discussion-the 'rules of the game' - that Shils observed in contemporary British politics with such admiration in later works (e.g. Shils, 1955b) were for Shils the modern expression of a traditional, elite culture of civil politics. The country's consensus-driven discourse excluded, notably, the totalizing worldviews that on the Continent had proven so destabilizing.

\footnotetext{
${ }^{6}$ Shils singled out John Locke's A Letter Concerning Toleration (1689) (Shils, 1975e: xiii) and Maurice Cowling (Shils, 1985: 175).
} 
British intellectuals were, for the most part, averse to Promethean ideals; they tended to accept, he observed, the limitations of politics, and they displayed a healthy attachment to their nation, its elites, and its traditions. The UK seemed to him a living riposte to the Schmittian gloom and cynicism about liberal democracy so common among German intellectuals fleeing the disastrous denouement of the Weimar experiment-a cynicism that he, too, had flirted with in the late 1930s.7

Shils' appreciation for the UK's achievement, which he saw essentially confirmed in the United States' own English traditions, was amplified in the immediate post-war years. He was appointed reader in sociology at the London School of Economics (LSE) in 1946, where he deepened his expo- sure, in particular, to the intellectual defence of the self-stabilizing English political order that was part of the LSEbased critique of Mannheimian planning by fellow émigrés Friedrich Hayek, Karl Popper, and Michael Polanyi (Pooley, 2007). Shils' sensitivity to order-maintaining liberal traditions was reinforced in his close friendship with Polanyi, in his LSE years and beyond. Shils' foray into the post-war politics of nuclear technology at the University of Chicago-where he remained on a half-time basis - supplied for Shils, in the form of a living community of responsible scientistintellectuals, a counter-ideal to the reckless, antinomian intellectual he had so long despised.

In this post-war period, Shils became convinced that utopia-drunk intellectuals had contributed to the disastrous collapse of continental societies. He was especially put off by the persisting claims of intellectuals, many of them leftist émigrés traumatized by National Socialism and the Holocaust, that modern society-and by implicit and explicit extension, the United States and the UK-were plagued by dangerously suggestible and atomized masses who could, yet again, yield to totalitarian demagogues. This was, to some degree, his own fear in the years leading up to the war, but he had since come to recognize the more complex, Gemeinschaft-persisting integration of all modern social orders, as well as the particular defences built up by the liberal Anglo-American societies.

To Shils, the complaints weren't just wrong, but also dangerous. In his view, their dystopian tracts resulted from bitter, morning-after disappointment, rooted in a contrast with their impossibly utopian beliefs. The distance between intellectuals' transcendent ideals and their actual, earthly societies, as Shils had observed all the way back to Flaubert, helps to explain their typical disgust for their own nations. In the lead-up to 1789, 1917, and 1933, the savage critiques of perfectionist intellectuals had in each case destabilized the social order; many of the same intellectuals had gone on, blinded by ide-

\begin{abstract}
${ }^{7}$ Shils' reflections on the British tradition of civility were not elaborated in published form in his wartime and post-war LSE period (1946-50), but were instead germinating in observation and close historical reading. His first sustained treatment of British and American pluralism came a few years later, in his remarkable, public intellectual denunciation of McCarthyism, The Torment of Secrecy (1956). Earlier expressions include Shils 1954a, 1954c, 1955c.
\end{abstract}


ological zeal, to help bring about human catastrophe. Even in the ashes of these disastrous experiments, many intellectuals gave in to a homeless, roving idealism in search of new utopias, or else succumbed to an icy, disillusioned 'realism'. Either way, the tendency among intellectuals has been to attack existing society and, in particular, exaggerate its faults.

In the post-war years, many American and émigré intellectuals on the Left-after giving up, in light of the all-too-many Kronstadts up to and including the formation of the post-war Eastern bloc, their socialist convictions-became disappointed radicals of the 'realist' stripe. Despite and because of their renunciation, they remained embittered by transcendent contrast, and prone to find their earthly societies deficient. In practice, Shils observed, their inveterate griping tended to take the form in these years of what he would come to call the 'theory of mass society' - an overemphasis on the Gesellschaftlike character of modern life, an exaggeration of consumer-culture soullessness, an inflated fear of the 'masses' ' susceptibility to demagogic propaganda (Shils [1957] 1972a; Shils, 1961b; Shils, 1962a). The picture put forward by these 1950 intellectuals was, he argued, a profoundly inaccurate displacement of their own disappointed ideals.

The crux, for Shils, was that the fragile Anglo-American liberal order depends on faith in its civil traditions of politics-a faith that the embittered ex-leftists threaten to corrode. Even before he codified this view in the late 1950 os in relation to his emergent categories of 'centre' and 'periphery', Shils came to regard these intellectuals' grim critique of American society and culture as a potentially cancerous element in America's plural politics. The risk, for Shils, was that the critics' mistaken picture would end up a kind of tragic self-fulfilling prophecy-by poisoning the well of public sentiment that the precious Anglo-American liberal order drinks from, either directly or by producing nativist, anti-intellectual backlashes whipped up by spurned and opportunistic politicians.

Shils made his point most forcefully back where he began: Georges Sorel. In Shils' 1950 introduction to the Free Press reissue of Reflections on Violence, Sorel remains the exemplar of all-or-nothing moral purity, the view that a 'total and drastic transformation of society' would bring about a 'total alleviation of life's ills' (Shils, 1950: 14). What Sorel so arrantly expressed is the 'aura of fever and exaltation' which surrounds the intel- lectual's sense of political promise (1950: 15). Even if the moral zeal of Sorel's socialism seemed, by 1950, spent, the underlying rejectionism was everywhere: 'The modern intelligentsia', Shils wrote, 'in all countries except Great Britain have, never since the 18th century, been in various forms of opposition to the prevailing society and the authorities who rule it' (1950: 
16). The opposition derives, Shils claimed as he would in more elaborate terms a few years later, from a sense of alienation from his countrymen and leaders.

Even without socialist commitments, the 'apocalyptic outsider's view of politics' remains; indeed, in an 'intellectually desiccated form', the stance is more widespread than 'ever before' (1950: 18). The same moral postulates drive, for example, the 'fanatical antiCommunism of the ex-Communists who, converted for a second time, trouble the world as much in one form as they did in the other, in all the insistence of the intelligentsia that goodness to be good must be perfection' (1950: 19). This apocalyptic separatism - this 'moral cleavage between the modern professional intellectual and primary institutions' - is incompatible with a 'free and orderly society' (1950: 21, 18). To Shils, Sorel was like a magnifying glass, rendering visible the otherwise-hidden rot of post-war intellectual life.

\section{Shils' manifesto}

In the first years after the war, Shils assumed the cocksure scientism and on-the-cusp bravado of other, less reflective social-science returnees. His Present State of American Sociology (1948) is a heady and brash book-almost a manifesto. When Shils wrote the text, he was still relatively unknown and unpublished, a lecturer without a Ph.D. or tenure. His breadth of knowledge, cutting prose style, and often severe assessments must have startled its disciplinary audience, as surely did the book's sharply critical diagnosis. Shils' argument is that American sociology remains in its pre-scientific infancy, despite some rich observations and promising research techniques. With nomothetic zeal, Shils exhorts his fellow sociologists to get on with the real science-general theory at a high level of abstraction research techniques. Sociology's 'present state' is one of 'backwardness' - it remains in the 'foothills of science', and not yet at its heights (1948: 63). The next year Shils joined Talcott Parsons at Harvard for the Carnegie-sponsored theory seminars, yielding their co-edited paean to abstraction, Toward a General Theory of Action (1951). As Shils (2006a) explained in his posthumously published autobiography, 'In the second half of the 1940s ... I believed in the redemptive power of systematic theory' (2006a: 81).

Like so many others at the time, he had the impression that Minerva's owl was set to take flight. Shils soon lost that faith: 'I engaged in the work of system-building with enthusiasm but also with reservations. Professor Parsons had even more enthusiasm and no reservations. When it was all over, I began to become aware of the flaws in what we had done, which remains nonetheless a very impressive 
achievement ... . It might well be possible to construct a coherent logical comprehensive system, with high explanatory power, in which more concrete concepts and hypotheses can be rigorously deduced from my general ones. However, after my experiences at the beginning of the 1950s, I have no temptation in that direction. ${ }^{8}$ Around this time, and just after publishing the Sorel introduction (Shils, 1950), he turned his attention back to his original puzzle. By 1952 he had completed a first draft of a book-length treatise, Intellectuals, which he would continue to revise and expand into the early 1970 (when the manuscript surpassed 1,500 pages). ${ }^{9}$ The book was never published, though as late as 1982 Shils wrote that he 'still hope[s] to come back to it, to reduce it and to release it from its present seclusion' (Shils, 1982c: xxiii).

It was during this post-Parsonsian hibernation that Shils adopted his omniscient, footnote-free prose-style-filling yellow notepads in greenink longhand. He became intimately involved in the Congress for Cultural Freedom, and spent a year in India for a Ford Foundation project on the Subcontinent's intellectuals. In both cases he was working on behalf of the Cold War national security state, providing - as it were-advice to princes. And he emerged with a fully-fledged theory of the intellectual: those persons with an unusual sensitivity to the sacred.

\section{References}

de Man, H. (1928 [1926]). The Psychology of Socialism. New York: Henry Holt and Co.

Fränkel, E. (1941). Dual State: A Contribution to the Theory of Dictatorship. New York: Oxford University Press, 1941.

Fromm, E. (1941). Escape From Freedom. New York: Farrar \& Rinehart, 1941.

Gerth, H. (1940). "The Nazi Party: Its leadership and composition." American Journal of Sociology, 45:4, 517-41.

Gunnell, J. G. (1993). The Descent of Political Theory: The Genealogy of an American Vocation. Chicago: University of Chicago Press.

Hansen, E. (1981). "Depression decade crisis: Social democracy and planisme in Belgium and the Netherlands, 1929-1939." Journal of Contemporary History, 16:2, 293-322.

Kennedy, E. (1987). "Carl Schmitt and the Frankfurt School." Telos, 71, 37-66.

Kettler, D. and V. Meja. (1995). “American hopes: The dispute over Ideology and Utopia." In Karl Mannheim and the Crisis of Liberalism (194-246). New Brunswick, NJ: Transaction.

Le Bon, G. (1982 [1898]). The Psychology of Socialism. New Brunswick,
${ }^{8}$ Shils (2006a: 85).

\begin{abstract}
${ }^{9}$ It is astonishing to realize that the Intellectuals manuscript was one of four lengthy, never-published projects Shils drafted in the early to mid-1950s: a 'full draft' of Consensus and Liberty: The Social Psychological Foundations of Political Democracy; a rougher draft of a book on primary groups; and 'an almost wholly new manuscript', a year or two later, on Love, Belief, and Civility (Shils, 1975e: xxviii).
\end{abstract}


NJ: Transaction Books.

Lederer, E. (1940). State of the Masses: The Threat of the Classless Society. New York: W. W. Norton \& Company.

Lerner, D. (1949). Sykewar: Psychological Warfare Against Germany, D-Day to VE-Day. New York: G. W. Stewart.

Locke, J. (1689). A Letter Concerning Toleration. London: Printed for Awnsham Churchill.

Mannheim, K. (1936 [1929]). Ideology and Utopia: An Introduction to the Sociology of Knowledge. New York: Harcourt, Brace \& World.

Mannheim, K. (1935 [1940]). Man and Society in an Age of Reconstruction: Studies in Modern Social Structure. New York: Harcourt, Brace \& World.

Michels, R. (1915 [1911]). Political Parties: A Sociological Study of the Oligarchical Tendencies of Modern Democracy. New York: Hearst's International Library Co.

Neumann, F. (1953). "The social sciences." In W. R. Crawford (ed), The Cultural Migration (4-26). Philadelphia: University of Pennsylvania.

Neumann, S. (1942). Permanent Revolution: The Total State in a World at War. New York: Harper \& Brothers.

Nye, R. A. (1973). "Two paths to a psychology of social action: Gustave LeBon and Georges Sorel." Journal of Modern History, 45:3, 411-38.

Nye, R. A. (1977). The Anti-Democratic Sources of Elite Theory: Pareto, Mosca, Michels. Beverly Hills, CA: Sage.

Oakes, G. and A. J. Vidich. (1999). "Gerth, Mills, and Shils: The Origins of From Max Weber." International Journal of Politics, Culture, and Society, 12:3, 399-433.

Parsons, T. and E. A. Shils. (1951). Toward a General Theory of Action. Cambridge, MA: Harvard University Press.

Pels, D. (1991). "Treason of the intellectuals: Paul De Man and Hendrik De Man." Theory, Culture and Society, 8:1, 21-56.

Pels, D. (2002). "Socialism between fact and value: From Tony Blair to Hendrik De Man and back." Journal of Political Ideologies, 7:3, 281-99.

Peyre, H. (1949). "The influence of Eighteenth Century ideas on the French Revolution." Journal of the History of Ideas, 10:1, 63-87.

Pitt, A. (1998). "The irrationalist liberalism of Hippolyte Taine." The Historical Journal, 41:4, 1035-53.

Pooley, J. (2006). "An Accident of Memory: Edward Shils, Paul Lazarsfeld, and the History of American Mass Communication Research." PhD dissertation, Columbia University.

Pooley, J. (2007). "Edward Shils' Turn Against Karl Mannheim: The Central European Connection." The American Sociologist, 38:4, 
$364-82$.

Scaff, L. A. (1981). "Max Weber and Robert Michels." American Journal of Sociology, 86:6, 1269-86.

Shils, E. A. (1935). Letter to Torsten Gordland (September 20), folder Correspondence 1930s, Box 1, Series IIII, Edward Shils Papers, University of Chicago Special Collections.

Shils, E. A. (1947). Memo to Daniel Lerner (January 9), folder Correspondence 1947 (3), box 1, Series III, Edward Shils Papers, University of Chicago Special Collections.

Shils, E. A. (1948b). The Present State of American Sociology. Glencoe, IL: Free Press.

Shils, E. A. (1950). "Introduction." In G. Sorel, Reflections on Violence (13-29). Glencoe, IL: Free Press.

Shils, E. A. (1954a). "The scientific community: Thoughts after Hamburg." Bulletin of the Atomic Scientists, 10:5, 151-55.

Shils, E. A. (1954b). "Authoritarianism, 'right and left'." In R. Christie and M. Jahoda (eds), Continuities in Social Research II: Studies in the Scope and Method of 'The Authoritarian Personality' (24-29). Glencoe, IL: Free Press.

Shils, E. A. (1954c). "Populism and the rule of law." In University of Chicago Law School Conference on Jurisprudence and Politics (91-107, April).

Shils, E. A. (1955a). “The intellectuals I: Great Britain." Encounter, 4:4, 1-12.

Shils, E. A. (1955b). "The end of ideology?" Encounter, 5 (Nov.): 52-58.

Shils, E. A. (1956). The Torment of Secrecy: The Background and Consequences of American Security Policies. Glencoe, IL: Free Press.

Shils, E. A. (1957a). "Personal, primordial, sacred, and civil ties." British Journal of Sociology, 8:2, 130-45.

Shils, E. A. (1957b). "Daydreams and nightmares: Reflections on the criticism of mass culture." The Sewanee Review, 65:4, 587-608.

Shils, E. A. (1958). "The intellectuals and the powers: Some perspectives for comparative analysis." Comparative Studies in Society and History, 1:1, 5-22.

Shils, E. A. (1961). "Mass society and its culture." In N. Jacobs (ed), Culture for the Millions? Mass Media in Modern Society (1-27). Princeton, NJ: Van Nostrand.

Shils, E. A. (1962). "The theory of mass society." Diogenes, 39, 45-66.

Shils, E. A. (1972). "Introduction." In E. A. Shils, The Intellectuals and the Powers and Other Essays (vii-xiii). Chicago: University of Chicago Press.

Shils, E. A. (1975). "Introduction." In E. A. Shils, Center and Periphery: Essays in Macrosociology (vii-xliii). Chicago: University of Chicago Press. 
Shils, E. A. (1981). "Some academics, mainly in Chicago." American Scholar, 50:2, 179-96.

Shils, E. A. (1982). "Introduction." In E. A. Shils, The Constitution of Society (vii-xxx). Chicago: University of Chicago Press.

Shils, E. A. (1985). "On the eve: A prospect in retrospect." In M. Bulmer (ed), Essays on the History of British Sociological Research (165-80). Cambridge: Cambridge University Press.

Shils, E. A. (1988). "Center and periphery: An idea and its career, 1935-1987." In L. Greenfield and M. Martin (eds), Center: Ideas and Institutions (250-64). Chicago: University of Chicago Press.

Shils, E. A. (1995). "Karl Mannheim." American Scholar, 64:2, 221-35.

Shils, E. A. (2006). A Fragment of a Sociological Autobiography: The History of My Pursuit of a Few Ideas. New Brunswick, NJ: Transaction.

Shils, E. A. and M. Janowitz. (1948). "Cohesion and Disintegration in the Wehrmacht in World War II." Public Opinion Quarterly, 12:2, 280-315.

Sombart, W. (1916). Der Moderne Kapitalismus. Munich: Duncker \& Humblot.

Sorel, G. (1908). Reflexions sur la violence. Paris: M. Riveáere et cie.

Sorel, G. (1987). "The ethics of socialism." In J. Stanley (ed), From Georges Sorel: Essays in Socialism and Philosophy (94-110). New York: Transaction.

Taine, H. (1875-1893). Les Origines de la France Contemporaine. Paris: Hachette.

Tillich, P. (1934). "The totalitarian state and the claims of the church." Social Research, 1, 405-33.

Tocqueville, A. (1998 [1856]). The Old Regime and the Revolution. Chicago: University of Chicago Press.

Turner, S. (1999). "The significance of Shils." Sociological Theory, 17:2, 125-45.

Weber, M. (1927 [1923]). General Economic History. New York: Greenberg.

Weber, M. (1946a [1919]). "Science as a vocation." In H. H. Gerth and C. W. Mills (eds), From Max Weber: Essays in Sociology (129-56). New York: Oxford University Press.

Weber, M. (1946b [1919]). "Politics as a Vocation." In H. H. Gerth and C. W. Mills (eds), From Max Weber: Essays in Sociology (77-128). New York: Oxford University Press.

Wirth, L. (1928). The ghetto. Chicago: University of Chicago Pres 